Digital Sociology 
This page intentionally left blank 


\section{Digital Sociology}

\section{Critical Perspectives}

Edited by

Kate Orton-Johnson

University of Edinburgh, UK

and

Nick Prior

University of Edinburgh, UK

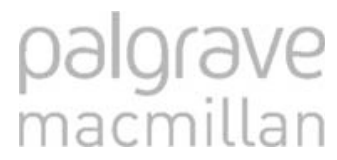




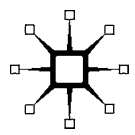

Selection, introduction and editorial matter (c) Kate Orton-Johnson and Nick Prior 2013

Individual chapters (c) their respective authors 2013

Softcover reprint of the hardcover 1st edition 2013 978-0-230-22282-3

All rights reserved. No reproduction, copy or transmission of this publication may be made without written permission.

No portion of this publication may be reproduced, copied or transmitted save with written permission or in accordance with the provisions of the Copyright, Designs and Patents Act 1988, or under the terms of any licence permitting limited copying issued by the Copyright Licensing Agency, Saffron House, 6-10 Kirby Street, London EC1N 8TS.

Any person who does any unauthorized act in relation to this publication may be liable to criminal prosecution and civil claims for damages.

The authors have asserted their rights to be identified as the authors of this work in accordance with the Copyright, Designs and Patents Act 1988.

First published 2013 by

PALGRAVE MACMILLAN

Palgrave Macmillan in the UK is an imprint of Macmillan Publishers Limited, registered in England, company number 785998, of Houndmills, Basingstoke, Hampshire RG21 6XS.

Palgrave Macmillan in the US is a division of St Martin's Press LLC, 175 Fifth Avenue, New York, NY 10010.

Palgrave Macmillan is the global academic imprint of the above companies and has companies and representatives throughout the world.

Palgrave ${ }^{\circledR}$ and Macmillan ${ }^{\circledR}$ are registered trademarks in the United States, the United Kingdom, Europe and other countries.

\section{ISBN 978-0-230-22283-0 ISBN 978-1-137-29779-2 (eBook) \\ DOI $10.1057 / 9781137297792$}

This book is printed on paper suitable for recycling and made from fully managed and sustained forest sources. Logging, pulping and manufacturing processes are expected to conform to the environmental regulations of the country of origin.

A catalogue record for this book is available from the British Library.

A catalog record for this book is available from the Library of Congress.

$\begin{array}{rrrrrrrrrr}10 & 9 & 8 & 7 & 6 & 5 & 4 & 3 & 2 & 1 \\ 22 & 21 & 20 & 19 & 18 & 17 & 16 & 15 & 14 & 13\end{array}$




\section{Contents}

List of Illustrations $\quad \mathrm{x}$

List of Contributors $\quad$ xi

Introduction $\quad \mathbf{1}$

Kate Orton-Johnson and Nick Prior

Relationships 4

Spaces $\quad 5$

$\begin{array}{ll}\text { Structures } & 6\end{array}$

$\begin{array}{ll}\text { Mediations } & 7\end{array}$

$\begin{array}{ll}\text { Practices } & 7\end{array}$

\section{Part I Relationships}

1 Personal Relationships, Intimacy and the Self in a Mediated and Global Digital Age

Lynn Jamieson

$\begin{array}{ll}\text { Introduction } & 13\end{array}$

Theorising the self in a digital age $\quad 14$

$\begin{array}{ll}\text { Theorising intimacy in a digital age } & 17\end{array}$

Mediation and modification of personal life: Imagining $\begin{array}{ll}\text { and seeking intimacy } & 20\end{array}$

Mediated relationships: Keeping and deepening intimacy? $\quad 24$

$\begin{array}{ll}\text { Conclusion } & 28\end{array}$

2 'Gendering the Digital': The Impact of Gender and Technology Perspectives on the Sociological Imagination

Eileen Green and Carrie Singleton

Introduction 34

Gendering the digital turn: Background debates 37

$\begin{array}{ll}\text { Feminist theories of technology } & 37\end{array}$

Our digital times 39

Gendering the digital turn: Mobile phones

in personal relationships 
Technology use and social connectedness $\quad 42$

The gendered dimensions of mobile sociality 43

Conclusions 46

3 Afterword: Digital Relationships and Feminist

Hope

Debra Ferreday

\section{Part II Spaces}

4 Rethinking Space: Urban Informatics and the Sociological Imagination

Roger Burrows and David Beer

What is urban informatics?

What is at stake sociologically? $\quad 62$

Towards a nomenclature $\quad 64$

Objects 66

Unitary coded objects and logjects $\quad 66$

Impermeable and permeable logjects $\quad 68$

$\begin{array}{ll}\text { Spimes } & 69\end{array}$

$\begin{array}{ll}\text { Assemblages } & 71\end{array}$

$\begin{array}{ll}\text { Augmented space } & 72\end{array}$

$\begin{array}{ll}\text { Enacted space } & 72\end{array}$

$\begin{array}{ll}\text { Transducted space } & 73\end{array}$

A sociological agenda...? $\quad 74$

5 Re-Thinking Community in the Digital Age? 79

Karen Evans

Expressions of community $\quad 79$

Building technological utopias $\quad 82$

Connecting and reconnecting in digital spaces 84

Cyberspace communities in an age of digital commerce

Final thoughts on community in the digital age $\quad 90$

6 Afterword: Digital Spaces, Sociology and Surveillance

David Lyon 


\section{Part III Structures}

7 Inequalities in the Network Society 105

Jan A. G. M. van Dijk

Introduction 105

$\begin{array}{ll}\text { Access and connectivity } & 107\end{array}$

$\begin{array}{ll}\text { Centrality } & 110\end{array}$

Variation and differentiation $\quad 112$

Selection and competition $\quad 113$

Differential mobility and speed $\quad 115$

Inequalities of skills $\quad 115$

Sociology and the theory of inequality in the digital age $\quad 117$

$\begin{array}{ll}\text { Policy directions } & 120\end{array}$

8 Trillions Out of Ones and Zeros: The Sociology of

Finance Encounters the Digital Age 125

Juan Pablo Pardo-Guerra

Introduction $\quad 125$

Studying finance $\quad 127$

Socialising finance 130

Information and market action 131

Knowledge, spatial and temporal elements

Materialities and financial practices 133

Conclusions 134

9 Digital Fields, Networks and Capital: Sociology beyond Structures and Fluids 139

Mike Savage

Information capital 140

'Machinic' or knowing capitalism? 142

Digital networks 144

$\begin{array}{ll}\text { Conclusions } & 146\end{array}$

\section{Part IV Mediations}

10 War Reporting in a Digital Age 151

Stuart Allan and Donald Matheson

War in a digital age $\quad 154$

The war for public opinion $\quad 160$

(De)legitimising power 164 
11 Imagining Networks: The Sociology of Connection in the Digital Age

Allison Cavanagh

Introduction

Networks and the cultural imaginary 170

Networks and the academy 173

What does it mean to see society as a network?

$\begin{array}{ll}\text { The Internet as a network } & 179\end{array}$

12 Afterword: Mediating the Digital 186

Nick Prior and Kate Orton-Johnson

\section{Part V Practices}

13 Rethinking Education in the Digital Age

Neil Selwyn

Introduction

Considering the promise of digital technology for the individual learner

Considering the realities of digital technology for the individual learner

Recognising the (dis)continuities of education

Conclusion

14 E-Health and Renewed Sociological Approaches to Health and Illness

Joëlle Kivits

Introduction

Health in a digital age or 'e-health': what is at stake?

Studying health and the Internet: the medical gaze $v s$. the sociological gaze

Renewed approaches to health and illness

in the era of the Internet

Revealing the healthy status: experiencing health online

Trust and expertise in the public-professional relationship 
Seeking and negotiating health information: some thoughts on agency

Conclusion

15 Afterword: Digital Technology and Sociological Windows

Andrew Webster

Index 


\section{Illustrations}

\section{Figures}

7.1 Potential tripartite structure of the network society

7.2 Kite network with different positions of centrality: highest degree (D), highest closeness (F) and highest betweenness $(\mathrm{H})$

\section{Tables}

4.1 A simplified summary of a conceptual framework for urban informatics (using only some of the key conceptual terms)

7.1 Types of (in)equality and (un)equally divided properties 


\section{Contributors}

Stuart Allan is Professor of Journalism in the Media School, Bournemouth University, UK.

David Beer is Senior Lecturer in Sociology in the Department of Sociology at the University of York, UK.

Roger Burrows is Professor of Sociology at Goldsmiths University, UK.

Allison Cavanagh is Lecturer and Researcher in Communications at the University of Leeds, UK.

Karen Evans is Senior Lecturer in Sociology, Social Policy and Criminology at the University of Liverpool, UK.

Debra Ferreday is Lecturer in Media and Cultural Studies at Lancaster University, UK.

Eileen Green is Emeritus Professor of Sociology at Teesside University, UK.

Lynn Jamieson is Professor of Sociology at the University of Edinburgh, UK.

Joëlle Kivits is Researcher at the University of Nancy, France.

David Lyon is Professor, Queen's Research Chair in Surveillance Studies at Queen's University, Canada.

Donald Matheson is Senior Lecturer in Media and Communication at the University of Canterbury, New Zealand.

Kate Orton-Johnson is Lecturer in Sociology at the University of Edinburgh, UK. 
Juan Pablo Pardo-Guerra is Lecturer at the London School of Economics and Political Science, UK.

Nick Prior is Senior Lecturer in Sociology at the University of Edinburgh, UK.

Mike Savage is Professor of Sociology at the London School of Economics, UK.

Neil Selwyn is a member of the Faculty of Education at Monash University, Australia.

Carrie Singleton is Research Fellow at Teesside University, UK.

Jan A. G. M. van Dijk is Professor of Communication Science at the University of Twente, The Netherlands.

Andrew Webster is Professor in the Sociology of Science and Technology at the University of York, UK. 